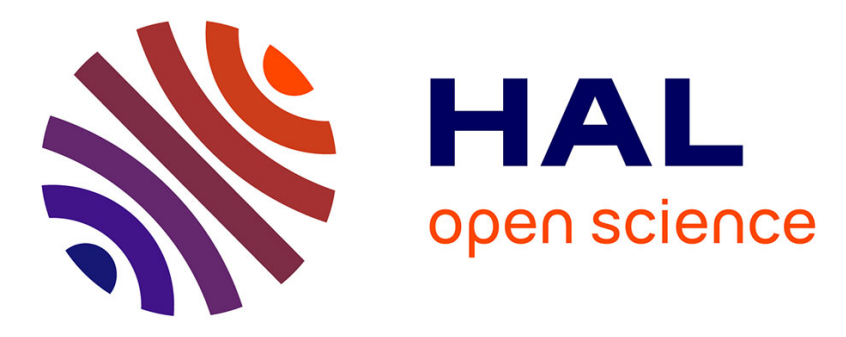

\title{
Transient simulation of halide perovskite-based solar cells with mobile ions and carriers
}

Yong Huang, Alexandre Gheno, Sylvain Vedraine, Laurent Pedesseau, Johann Bouclé, Jacky Even, Alain Rolland, Jean-Baptiste Puel, Marie-Estelle Gueunier-Farret

\section{To cite this version:}

Yong Huang, Alexandre Gheno, Sylvain Vedraine, Laurent Pedesseau, Johann Bouclé, et al.. Transient simulation of halide perovskite-based solar cells with mobile ions and carriers. 18th International Conference on Numerical Simulation of Optoelectronic Devices (NUSOD 2018), Nov 2018, Hong Kong, China. 10.1109/nusod.2018.8570250 . hal-01969296

\section{HAL Id: hal-01969296 https://hal.science/hal-01969296}

Submitted on 9 Jan 2019

HAL is a multi-disciplinary open access archive for the deposit and dissemination of scientific research documents, whether they are published or not. The documents may come from teaching and research institutions in France or abroad, or from public or private research centers.
L'archive ouverte pluridisciplinaire HAL, est destinée au dépôt et à la diffusion de documents scientifiques de niveau recherche, publiés ou non, émanant des établissements d'enseignement et de recherche français ou étrangers, des laboratoires publics ou privés. 


\section{Transient simulation of halide perovskite-based solar cells with mobile ions and carriers}

\author{
$1^{\text {st }}$ Yong Huang \\ Institut Photovoltaïque de l'île de \\ France (IPVF) \\ Palaiseau, France \\ yong.huang@ipvf.fr \\ $4^{\text {th }}$ Laurent Pedesseau \\ Univ Rennes, INSA Rennes, CNRS, \\ Institut FOTON - UMR 6082 \\ Rennes, France \\ laurent.pedesseau@insa-rennes.fr \\ $7^{\text {th }}$ Alain Rolland \\ Univ Rennes, INSA Rennes, CNRS, \\ Institut FOTON - UMR 6082 \\ Rennes, France \\ alain.rolland@univ-rennes1.fr
}

\author{
$2^{\text {nd }}$ Alexandre Gheno \\ XLIM UMR 7252, Université de \\ Limoges/CNRS \\ Limoges, France \\ alexandre.gheno@hotmail.fr \\ $5^{\text {th }}$ Johann Bouclé \\ XLIM UMR 7252, Université de \\ Limoges/CNRS \\ Limoges, France \\ johann.boucle@unilim.fr \\ $8^{\text {th }}$ Jean Baptiste Puel \\ Institut Photovoltaïque de l'île de \\ France (IPVF) \\ Palaiseau, France \\ jean-baptiste.puel@edf.fr
}

\author{
$3^{\text {rd }}$ Sylvain Vedraine \\ XLIM UMR 7252, Université de \\ Limoges/CNRS \\ Limoges, France \\ sylvain.vedraine@unilim.fr \\ $6^{\text {th }}$ Jacky Even \\ Univ Rennes, INSA Rennes, CNRS, \\ Institut FOTON - UMR 6082 \\ Rennes, France \\ jacky.even@insa-rennes.fr \\ $9^{\text {th }}$ Marie Gueunier-Farret \\ GEEPS, 11 rue Joliot Curie-Plateau \\ de Moulon \\ Gif sur Yvette, France \\ marie.farret@geeps.centralesupelec.fr
}

\begin{abstract}
Halide Perovskites are considered as solid semiconductors since the beginning of their solar cell development. However, on their film or devices, direct and indirect observations of mobile ions are currently reported. Mobile ions are included in the present study within the drift-diffusion approximations, in addition to general carriers. Ion migration inside the perovskite layer and the abnormal hysteresis effect in the current-voltage measurements are simulated in comparison with the experiments of classic perovskite solar cells. The work is promising for the advancements of halide-perovskite-based devices, such as solar cells, light emitting diodes, lasers, photodetectors, transistors, or memoirists.
\end{abstract}

Keywords-halide perovskite, ion migration, hysteresis

\section{INTRODUCTION}

More comprehensions of the halide perovskites accompany the robust improvement of their solar cells, whose record of the single junction [1] and 2-terminal tandem [2] are $22.7 \%$ and $25.2 \%$, respectively. Halide perovskite materials $\left(\mathrm{ABX}_{3}\right)$ share a similar cell structure with the classic mineral oxide perovskite $\left(\mathrm{ABO}_{3}\right)$. The cation A site is typically composed of organic methylammonium (MA), formamidinium (FA), or inorganic $\mathrm{Cs}$ or $\mathrm{Rb}$ cations. Generally, lead $(\mathrm{Pb})$ sits in the $\mathrm{B}$ site, and the $\mathrm{X}$ site is filled with halide atoms $\mathrm{I}, \mathrm{Br}$, or $\mathrm{Cl}$. Based on linear combinations of orbitals including spin-orbit coupling (SOC) [3], the atomistic computations explained that the appropriate absorption and transport properties are afforded by the multi-bandgap and multivalley nature of their band structure. This hypothesis is further confirmed by the study of the structural and optical properties [4]. The low effective mass of excitons in $\mathrm{MAPbI}_{3}$ was accurately determined using magneto-reflectivity at very high magnetic fields model [5]. As a result, halide perovskites are considered as solid semiconductors [6] with an efficient photo-conversion. Nevertheless, many groups recently reported the direct and indirect measurements [7][8] of mobile ions inside halide perovskites under different operation conditions, which is quite different from the traditional silicon or III-V materials. The ion migration is assumed to contribute to one of the major instabilities of perovskite solar cells (PSCs), the abnormal hysteresis effect [9], which means the current-voltage $(\mathrm{J}-\mathrm{V})$ characteristics depends on the scan rate, the scan direction or the precondition. With such effect, the effective photon-to-electron conversion eficiency could be questioned.

In the study, the drift-diffusion approximations and the continuity equations of electrons and holes are extended in the simulator atlas to consider ions moving inside the perovskite layer. One of the most widely studied compounds, $\mathrm{MAPbI}_{3}$ perovskite is chosen to investigate the ion migration within the $\mathrm{TiO}_{\mathrm{x}} / \mathrm{MAPbI}_{3} /$ Spiro-OMeTAD architecture. The simulated ion migration and the corresponding hysteresis effect are presented and discussed.

\section{MODELING AND DISCUSSION}

The architecture is experimentally studied as mentioned in the previous report [10]. The anatase $\mathrm{TiO}_{\mathrm{x}}(165 \mathrm{~nm}$-thick) is the electron transport layer, and the Spiro-OMeTAD (50 nm-thick) is the hole transport layer, sandwiching the absorber $\mathrm{MAPbI}_{3}$ (total $335 \mathrm{~nm}$-thick). The $135 \mathrm{~nm}$-thick $\mathrm{MAPbI}_{3}$ is related to the part inside the porosity of mesoporous $\mathrm{TiO}_{\mathrm{x}}$ layer. The electrodes are Ohmic. The photo-induced carrier generation processes are introduced by the complex refractive index of the materials, in addition to the bimolecular recombination, and the trap-assisted recombination in the bulk and at the $\mathrm{TiO}_{\mathrm{x}} / \mathrm{MAPbI}_{3}$ interface.

The schematic architecture of PSC is drawn (Fig. 1), along with the simulated band alignment and the electric field $\left(\mathrm{E}_{\mathrm{fd}}\right)$. Two $\mathrm{E}_{\mathrm{fd}}$ spikes in a logarithm scale are related to two hetero-junctions, while the $\mathrm{E}_{\mathrm{fd}}$ is uniform in the middle. In the dark and short circuit (Fig. 2 a-c), carriers are depleted under built-in potential, and the negative ions accumulate near the $\mathrm{TiO}_{\mathrm{x}}$ layer, where the ionized dopants are positive. Under illumination of one sun and $1.5 \mathrm{~V}$ bias (Fig. $2 \mathrm{~d}-\mathrm{f}$ ), the perovskite layer is filled with photo-generated carriers, and the negative ions shift towards to the positively biased anode. After preconditioned under one sun and $1.5 \mathrm{~V}$ bias for 20 seconds, the $\mathrm{J}-\mathrm{V}$ characterization is performed from 0 to 1.5 $\mathrm{V}$ then back to $0 \mathrm{~V}$. The hysteresis effect is observed in the experiments and simulations (Fig. 3). The variation of the open circuit voltage is well reproduced, while the difference of the short-circuit current might come from the thickness of 


\section{NUSOD 2018}

the $\mathrm{MAPbI}_{3}$ layer or the device surface area. The simulated $\mathrm{J}-\mathrm{V}$ characteristic above $1 \mathrm{~V}$ shows a similar trend to the experiments, indicating a saturation of the ion migration. According to the simulation in the study, the interface recombination at $\mathrm{TiO}_{\mathrm{x}} / \mathrm{MAPbI}_{3}$ is mandatory to reproduce the hysteresis effect, besides the ion migration. This might interpret the observation of ion migration in the inverted PSCs, however, who are almost free of the hysteresis effect. The interface condition between perovskite and PCBM is assumed to be better than that at $\mathrm{TiOx} / \mathrm{MAPbI}_{3}$ interface.

a)

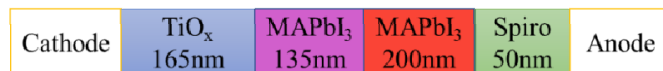

b)

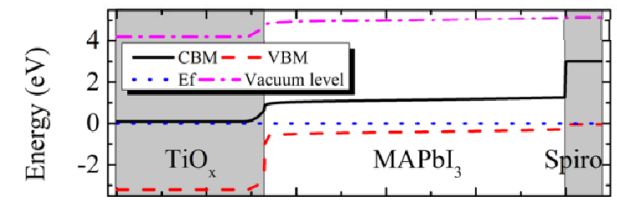

c)

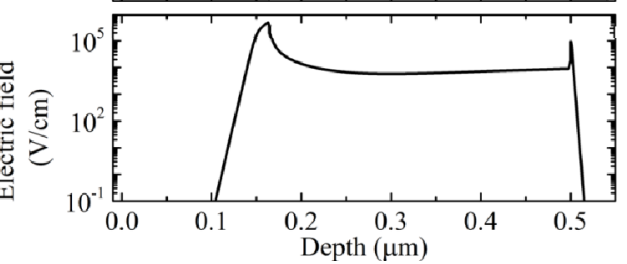

Fig. 1. a) Schematic architecture of PSCs, b) the simulated band alignment and c) the electric field profile. The band alignment and the electric field share the same x-axis. Spiro is short for Spiro-OMeTAD.

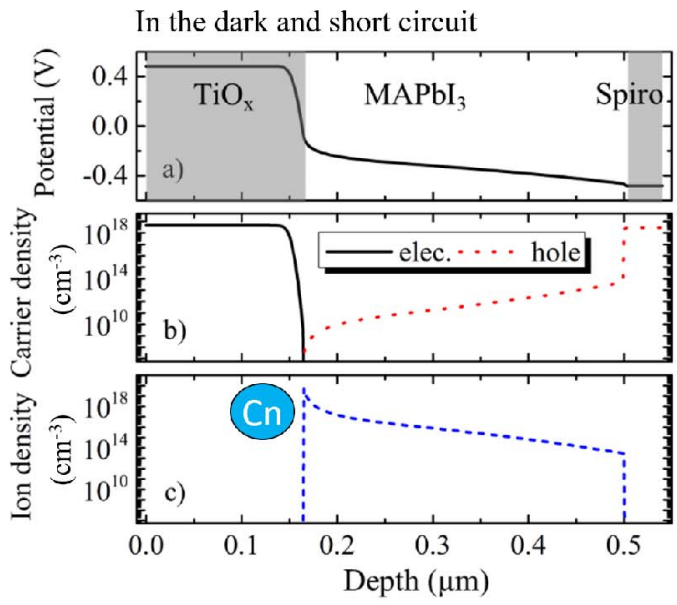

Under light and $1,5 \mathrm{~V}$ bias
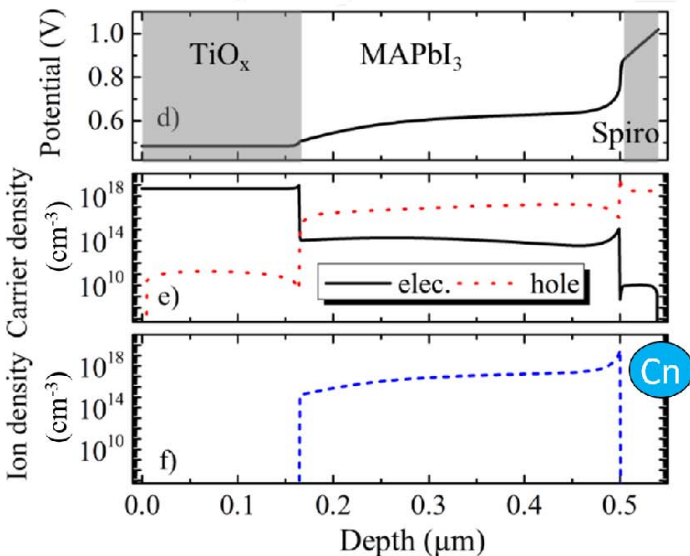

Fig. 2. Potential, carrier and ion density a-c) in the dark and short circuit, $\mathrm{d}-\mathrm{f}$ ) under light and $1.5 \mathrm{~V}$ bias. $\mathrm{Cn}$ indicates major part of the negative ions.
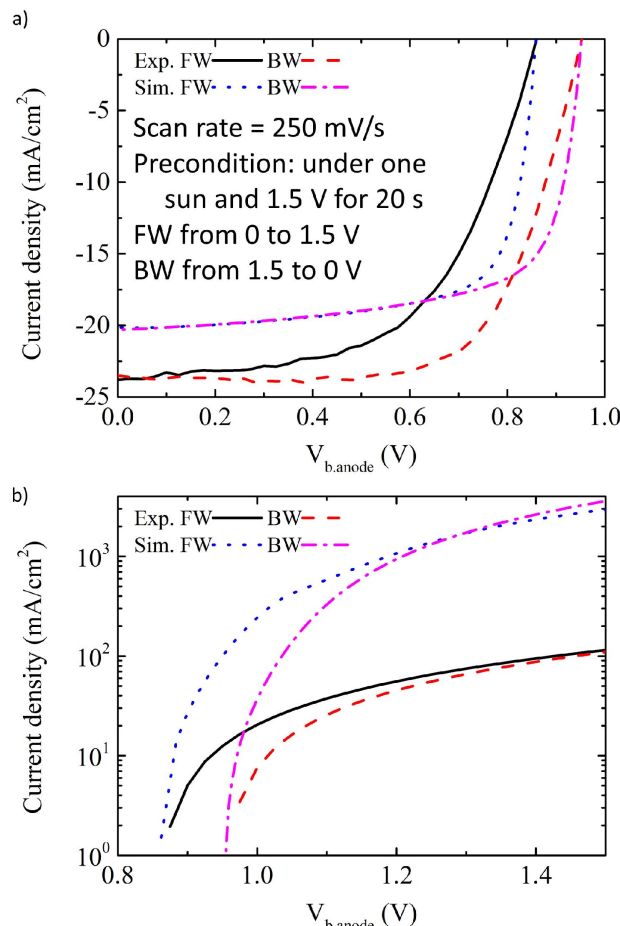

Fig. 3. Experimental and simulated hysteresis $\mathrm{J}-\mathrm{V}$ characteristics. FW is the forward scan and BW is the backward scan. Before any scan, the devices are preconditioned under one sun and $1.5 \mathrm{~V}$ bias for 20 seconds. The y-axis in b) uses a logarithm scale.

\section{REFERENCES}

[1] "Best Research-Cell Efficiencies chart," National Renewable Energy Laboratory (NREL), 2018. [Online]. Available: https://www.nrel.gov/pv/assets/images/efficiency-chart.png. [Accessed: 25-Apr-2018].

[2] F. Sahli et al., "Fully textured monolithic perovskite/silicon tandem solar cells with $25.2 \%$ power conversion efficiency," Nat. Mater., no. accepted/in press, p. 1, Jun. 2018.

[3] J. Even, L. Pedesseau, and C. Katan, "Analysis of multivalley and multibandgap absorption and enhancement of free carriers related to exciton screening in hybrid perovskites," J. Phys. Chem. C, vol. 118, no. 22, pp. 11566-11572, Jun. 2014.

[4] H.-H. Fang, F. Wang, S. Adjokatse, N. Zhao, J. Even, and M. A. Loi, "Photoexcitation dynamics in solution- processed formamidinium lead iodide perovskite thin films for solar cell applications Running Title: Optical properties of a hybrid perovskite," Light Sci. Appl., vol. 5, no. November 2015, pp. e16056-7, Apr. 2016.

[5] A. Miyata et al., "Direct measurement of the exciton binding energy and effective masses for charge carriers in organic-inorganic tri-halide perovskites," Nat. Phys., vol. 11, no. 7, pp. 582-587, Jul. 2015.

[6] J. Even et al., "Solid-state physics perspective on hybrid perovskite semiconductors," J. Phys. Chem. C, vol. 119, no. 19, pp. 10161-10177, May 2015.

[7] H. Lee et al., "Direct Experimental Evidence of Halide Ionic Migration under Bias in CH3NH3PbI3-xClx-Based Perovskite Solar Cells Using GD-OES Analysis," ACS Energy Lett., vol. 2, no. 4, pp. 943-949, Apr. 2017.

[8] C. Li, A. Guerrero, Y. Zhong, and S. Huettner, "Origins and mechanisms of hysteresis in organometal halide perovskites," Journal of Physics Condensed Matter, vol. 29, no. 19. IOP Publishing, p. 193001, 17-May-2017.

[9] H. J. Snaith et al., "Anomalous hysteresis in perovskite solar cells," $J$. Phys. Chem. Lett., vol. 5, no. 9, pp. 1511-1515, May 2014.

[10]A. Gheno, T. T. Thu Pham, C. Di Bin, J. Bouclé, B. Ratier, and S. Vedraine, "Printable WO3 electron transporting layer for perovskite solar cells: Influence on device performance and stability," Sol. Energy Mater. Sol. Cells, vol. 161, pp. 347-354, Mar. 2017. 